\title{
Renal ultrastructure, renal function, and parameters of lead toxicity in workers with different periods of lead exposure
}

\author{
KIM CRAMÉR, ROBERT A. GOYER, RUDOLF JAGENBURG, and \\ MARION H. WILSON \\ Department of Hygiene, Västra Frolunda Sjukvårdscentral, and Department of Clinical \\ Chemistry, University of Göteborg, City of Göteborg, Sweden, and Department of \\ Pathology, University of North Carolina School of Medicine, Chapel Hill, North \\ Carolina, USA
}

\begin{abstract}
Cramér, K., Goyer, R. A., Jagenburg, R., and Wilson, Marion H. (1974). British Journal of Industrial Medicine, 31, 113-127. Renal ultrastructure, renal function, and parameters of lead toxicity in workers with different periods of lead exposure. Renal biopsies were obtained from five men with heavy occupational exposure to lead and compared with studies of their renal function and parameters of lead toxicity. Two men had lead exposure of less than one year while three men had been exposed for from four to more than 30 years. In addition, renal function studies were performed in two men from whom renal biopsies could not be obtained. Their lead exposures were five and 12 years, respectively. Significantly lower plasma levels, when compared with non-exposed controls, were found for proline, valine, tyrosine, and phenylalanine although no excessive aminoaciduria was found. Renal function tests were normal in all except for a reduced glomerular filtration rate (GFR) in one worker. Plasma ALA was measured by a new and highly specific method and ALA clearance was found to follow GFR closely. Those workers with prolonged lead exposure showed a lower urinary lead excretion. Typical lead-induced intranuclear inclusion bodies were found only in those with short exposure. The ultrastructural changes were localized to the proximal tubules, while the glomeruli were only nonspecifically affected. Mitochondrial changes were found in all men. Reasons for the decrease in inclusion body formation in chronic lead nephropathy are uncertain but may be due to an increased rate of renal cell turnover or a consequence of chelation therapy.
\end{abstract}

The potential renal effects of lead extend from reversible proximal tubular dysfunction and ultrastructural changes to a chronic nephropathy and renal failure (Goyer, 1971a). During acute lead poisoning there is formation of nuclear inclusion bodies which have been shown to be a lead-protein complex (Goyer, May, Cates, and Krigman, 1970). Other ultrastructural changes include alterations in mitochondria which are thought to reflect impairment of respiration and phosphorylation (Goyer,
1968; Goyer, Krall, and Kimball, 1968). Renal tubular dysfunction is often present in children with acute lead intoxication and is shown by excessive aminoaciduria, glucosuria, and hyperphosphaturia (Chisolm, 1962). These changes appear to be similar in man and experimental animals. However, human adults with heavy exposure to lead usually have little or no excessive aminoaciduria (Goyer, Tsuchiya, Leonard, and Kahyo, 1972).

The transition from the acute renal effects of lead 
to a chronic nephropathy has been described in experimental animals, and a form of lead-induced chronic nephropathy has long been suspected to occur in man. However, the morbid anatomical changes induced by lead that result in renal failure have not been well documented nor have the renal effects of lead been related to an individual's ability to excrete lead or his susceptibility to other toxic manifestations of lead exposure.

The present study of renal biopsies from lead workers with varying intervals of exposure to lead correlates the presence of inclusion bodies in renal tubular lining cells with renal lead excretion, renal function tests, as well as with the severity of several parameters of lead toxicity. It should be pointed out that this group of workmen reflects a single form of lead exposure from the handling of scrap metals. The characteristics of this occupation have been described by McCallum (1963) and Rieke (1969).

\section{Materials and methods}

\section{Clinical material}

Five men aged 26 to 66 years, employed at a shipwrecking yard in Göteborg, were studied. They were all cutting through old steel ship-hulls with acetyleneoxygen torches. The temperature of the flame was about $2000^{\circ} \mathrm{C}$. Before they cut into the steel they had to burn away a surface layer of lead-containing paint, mainly red lead. The paint layer could be $4-5 \mathrm{~mm}$ thick. During the study period an old naval vessel with heavy lead-containing paint layers was cut. Previous experience from the same workplace has shown that the cutting of naval ships is accompanied by an excessive exposure to lead and subsequently more cases of lead poisoning than occur after cutting other types of ships. At the temperature of the acetylene-oxygen torch lead oxide is reduced to the metallic state and evaporated. The gaseous lead is rapidly oxidized in air, forming a lead fume of very small particle size, which is readily inhaled. All workers had access to protective masks but did not use them, as they were regarded as unnecessary and moreover diminished the work yield and thereby also their income. Measurements of lead in air at the workplace were not carried out. Such measurements must be performed with personal samplers to give reliable results (Williams, King, and Walford, 1969) and as the scrap-burners move rather freely during their working day it was decided that measurements would not be reliable. However, from the experiences of ship metal burners reported by McCallum (1963) and Rieke (1969), air levels exceeding the threshold limit value of $0.2 \mathrm{mg} / \mathrm{m}^{3}\left(200 \mu \mathrm{g} / \mathrm{m}^{3}\right)$ can be expected. Routine surveillance of the workers has generally placed them in the group of 'excessive absorption' or 'dangerous absorption' (Lane et al., 1968). The workers had regular rest intervals, and the patients included in this study were either picked up at one of these periods or after admissions to hospital because of clinically overt lead poisoning.

Six of the men included in the study had liberal habits of drinking alcohol, most of them admitting a daily consumption or excessive drinking over week-ends.
In all cases admission to hospital took place on a Monday, and the men had been busy in their usual occupation with exposure to lead until the preceding Friday afternoon. In four cases renal biopsy was carried out the next Wednesday, i.e., 11 days after final lead exposure. In these cases no chelation therapy was given prior to biopsy. Case A.C. developed a very painful lead colic and oral therapy with $\delta$-penicillamine was instituted 48 hours before renal biopsy.

\section{Case histories}

Case J.V., 26 years of age. He was previously employed at a shipyard but had been engaged in scrap metal cutting in a ship-breaking yard for eight months prior to the study. Three months before the study he was admitted to hospital because of lead colic and was treated with $\delta$-penicillamine with a good clinical effect. He returned to the same work but, in spite of warnings, did not use a protective mask. He was readmitted to hospital five months later because of laboratory signs of excessive to dangerous lead absorption (Tables 1 and 2). He did not complain of any symptoms of lead poisoning, i.e., he did not feel tired; he had no abdominal pain, no muscular cramps or weakness, and no constipation. With regard to his symptomatology it may be remarked that he was entirely Finnish-speaking, rather taciturn, and unwilling to admit any illness.

Case V.M., 35 years of age. Previous occupations were in forestry and at an iron foundry. There was no previous exposure to lead. He was admitted to hospital because routine examination after six weeks' employment in scrap-metal handling indicated dangerous lead absorption (Tables 1 and 2). His only clinical symptom was limited to some gastric discomfort without colic, fatigue, muscular symptoms or constipation. This man was also entirely Finnish-speaking and unwilling to admit any complaints.

Case A.C., 41 years of age. He had been employed in scrap-metal handling for the previous ten years. He had been admitted to hospital eight times between 1963 and 1967 because of lead poisoning, generally with a previous weight loss of 5 to $6 \mathrm{~kg}$, abdominal pain, constipation and/ or diarrhoea, general muscular weakness, and painful muscular cramps. He often complained of a sweetish metallic taste. His work-mates generally recognized his impending lead poisoning with the onset of bad temper. An anaemia of about 10.5-10.8 haemoglobin/100 ml was found several times. He had had positive Burton's lines for many years. He always responded well to courses of treatment with either $\delta$-penicillamine or calcium disodium edetate. D-penicillamine was used routinely and edetate only in comparative studies between this drug and $\delta$ penicillamine (Selander, 1967). In spite of repeated advice to get another job, this man stuck to scrap-metal cutting, seeking employment in different companies. In addition to the recorded poisonings with hospital treatment he admits at least five additional periods when he felt too weak to go to work, but he did not always seek medical care. He was seen by us twice in hospital. On the first occasion he was admitted because of severe colic with clear signs of lead intoxication (Table 1). An attempt at renal biopsy at that time was unsuccessful but studies of renal function were performed (Table 2). His colic was intense and prompted treatment with $\delta$ - 
TABLE 1

Clinical Material including Duration of Lead Exposure, Urinary Concentrations, and 24-Hour Outputs of Lead and ALA, and Electron Microscopical Findings of Nuclear INCLusion Bodies in Proximal Renal Tubule Cells

\begin{tabular}{|c|c|c|c|c|c|c|c|c|c|}
\hline $\begin{array}{c}\text { Patient } \\
\text { (age) }\end{array}$ & $\begin{array}{c}\text { Lead } \\
\text { exposure } \\
(y r)\end{array}$ & $\begin{array}{l}\text { Haemo- } \\
\text { globin } \\
(\mathrm{g} / 100 \mathrm{ml})\end{array}$ & $\begin{array}{c}\text { Serum } \\
\text { uric acid } \\
(\mathrm{mg} / 100 \mathrm{ml})\end{array}$ & $\begin{array}{c}\text { Blood } \\
\text { lead } \\
(\mu \mathrm{g} / 100 \mathrm{ml})\end{array}$ & \multicolumn{2}{|c|}{$\begin{array}{c}\text { Urinary } A L A \\
(\mathrm{mg} / 100 \mathrm{ml}) \\
(\mathrm{mg} / 24 \mathrm{hr})\end{array}$} & \multicolumn{2}{|c|}{$\begin{array}{c}\text { Urinary lead } \\
(\mu g / l) \\
(\mu g / 24 h r)\end{array}$} & $\begin{array}{c}\text { Kidney } \\
\text { nuclear } \\
\text { inclusions }\end{array}$ \\
\hline $\begin{array}{l}\text { J.V. } \\
\text { (26) }\end{array}$ & $8 / 12$ & $12 \cdot 2$ & $6 \cdot 6$ & $\begin{array}{r}103 \\
89\end{array}$ & $\begin{array}{l}5 \cdot 84 \\
5 \cdot 40 \\
4 \cdot 86 \\
2 \cdot 92\end{array}$ & $\begin{array}{l}65 \cdot 4 \\
63 \cdot 7 \\
48 \cdot 4 \\
45 \cdot 0\end{array}$ & $\begin{array}{l}370 \\
280 \\
340 \\
250\end{array}$ & $\begin{array}{l}414 \\
330 \\
338 \\
385\end{array}$ & Positive \\
\hline $\begin{array}{l}\text { V.M. } \\
\text { (35) } \\
\text { A.C. } \\
\text { (41) }\end{array}$ & $\begin{array}{r}6 / 52 \\
10\end{array}$ & $\begin{array}{r}11 \cdot 2 \\
9 \cdot 1\end{array}$ & $\begin{array}{l}3.9 \\
9.2\end{array}$ & $\begin{array}{l}129 \\
138\end{array}$ & $\begin{array}{r}5 \cdot 06 \\
4 \cdot 47 \\
16 \cdot 36\end{array}$ & $\begin{array}{r}70 \cdot 8 \\
96 \cdot 1 \\
186 \cdot 5\end{array}$ & $\begin{array}{l}310 \\
220 \\
240 \\
270\end{array}$ & $\begin{array}{l}434 \\
483 \\
274 \\
240\end{array}$ & $\begin{array}{l}\text { Positive } \\
\text { Negative }\end{array}$ \\
\hline $\begin{array}{l}\text { K.G. } \\
(47) \\
\begin{array}{l}\text { K.H. } \\
(66)\end{array}\end{array}$ & 20 & $\begin{array}{l}11 \cdot 0 \\
13 \cdot 1\end{array}$ & 5.9 & $\begin{array}{r}77 \\
71 \\
\\
109 \\
104\end{array}$ & $\begin{array}{l}9 \cdot 26 \\
5 \cdot 60 \\
5 \cdot 00 \\
7 \cdot 29 \\
4 \cdot 22\end{array}$ & $\begin{array}{l}76 \cdot 9 \\
52 \cdot 6 \\
56.5 \\
87.5 \\
54.9\end{array}$ & $\begin{array}{l}143 \\
430 \\
290 \\
290 \\
200 \\
110\end{array}$ & $\begin{array}{l}262 \\
346 \\
273 \\
273 \\
240 \\
143\end{array}$ & $\begin{array}{l}\text { Negative } \\
\text { Negative }\end{array}$ \\
\hline $\begin{array}{l}\text { V.S. } \\
\text { (46) } \\
\text { B.J. } \\
\text { (55) }\end{array}$ & $\begin{array}{r}5 \\
11\end{array}$ & $\begin{array}{r}8 \cdot 5 \\
11 \cdot 8\end{array}$ & $\begin{array}{l}8 \cdot 0 \\
3 \cdot 0\end{array}$ & 80 & $\begin{array}{l}8 \cdot 17 \\
3 \cdot 58\end{array}$ & $\begin{array}{l}37 \cdot 3 \\
50 \cdot 8\end{array}$ & $\begin{array}{r}70 \\
205\end{array}$ & $\begin{array}{r}80 \\
161\end{array}$ & $\begin{array}{l}\text { Not } \\
\text { examined } \\
\text { Not } \\
\text { examined }\end{array}$ \\
\hline
\end{tabular}

All values for cases above the line refer to conditions immediately before treatment, except A.C., who was biopsied four months later when blood lead was $204 \mu \mathrm{g} / 100 \mathrm{ml}$, urinary ALA $19.60 \mathrm{mg} / 100 \mathrm{ml}$, and haemoglobin $8.8 \mathrm{~g} / 100 \mathrm{ml}$. All these, except A.C., were biopsied before treatment.

Values for cases below the line refer to conditions immediately prior to renal clearance studies. These cases were not biopsied. The renal clearance studies were performed before treatment.

TABLE 2

Plasma Ala Concentration and Renal Function in 7 Subjects with Excessive or Dangerous Lead ABSORPTION

\begin{tabular}{|c|c|c|c|c|c|c|c|c|c|c|c|}
\hline \multicolumn{6}{|c|}{ Patient } & \multicolumn{2}{|c|}{\begin{tabular}{cc}
\multicolumn{2}{c}{ Serum } \\
ALA & Creatinine \\
$(\mu \mathrm{mol} / \mathrm{l})$ & $(\mathrm{mg} / 100 \mathrm{ml})$ \\
\end{tabular}} & \multicolumn{3}{|c|}{\begin{tabular}{cc}
\multicolumn{2}{c}{ Renal clearance } \\
ALA Inuline PAH \\
(ml/min) & $\left(1 \cdot 73 \mathrm{~m}^{2}\right)$
\end{tabular}} & \multirow{2}{*}{$\begin{array}{c}\begin{array}{c}\text { Filtration fraction } \\
C_{I n} / C_{P A H}\end{array} \\
0 \cdot 14\end{array}$} \\
\hline J.V. & . & . & . & . & . & $\begin{array}{l}4 \cdot 8 \\
4 \cdot 2\end{array}$ & $1 \cdot 3$ & 102 & 96 & 690 & \\
\hline V.M. & . & . & . & . & .. & $\begin{array}{l}4 \cdot 6 \\
4 \cdot 4\end{array}$ & 0.8 & 98 & 128 & 888 & $0 \cdot 14$ \\
\hline A.C. & . & . & . & . & . & $\begin{array}{l}10 \cdot 8 \\
10 \cdot 8\end{array}$ & $1 \cdot 1$ & 40 & 65 & 600 & $0 \cdot 11$ \\
\hline K.G. & . & . & . & . & . & $\begin{array}{l}1 \cdot 0 \\
1.2\end{array}$ & $1 \cdot 0$ & 111 & 93 & 720 & $0 \cdot 13$ \\
\hline K.H. & .. & . & . & . & .. & $\begin{array}{l}2 \cdot 4 \\
2 \cdot 2\end{array}$ & 0.7 & 111 & 121 & 693 & $0 \cdot 18$ \\
\hline V.S. & .. & . & . & .. & . & $\begin{array}{l}6 \cdot 0 \\
7 \cdot 2\end{array}$ & $1 \cdot 1$ & 60 & 75 & 495 & $0 \cdot 15$ \\
\hline B.J. & . & . & . & . & . & $\begin{array}{l}2 \cdot 6 \\
2 \cdot 5\end{array}$ & $1 \cdot 0$ & 82 & 78 & 613 & $0 \cdot 13$ \\
\hline \multicolumn{3}{|c|}{ Reference value } & . & . & .. & $<0.2$ & $\begin{array}{l}0 \cdot 6- \\
1 \cdot 3\end{array}$ & - & $\begin{array}{l}90- \\
150\end{array}$ & $\begin{array}{l}500- \\
800\end{array}$ & $\begin{array}{l}0.17- \\
0.23\end{array}$ \\
\hline
\end{tabular}


penicillamine, $500 \mathrm{mg}$ four times daily, which relieved him of all symptoms within 10 hours. In spite of warnings he returned to his old occupation after less than two months. $\mathrm{He}$ had to be readmitted to the emergency ward because of severe abdominal pain two months later. A tentative diagnosis of gastric rupture was ruled out and he was sent to a medical ward with the diagnosis of lead poisoning. Besides severe colic he had a metallic taste, general fatigue, and marked pallor. His blood lead was 204 $\mu \mathrm{g} / 100 \mathrm{ml}$ and urinary $\delta$-aminolevulinic acid (ALA) concentration was $19.60 \mathrm{mg} / 100 \mathrm{ml}$. Twenty-four hour volumes could not be obtained. Haemoglobin was 8.8 $\mathrm{g} / 100 \mathrm{ml}$ and serum creatinine $1.1 \mathrm{mg} / 100 \mathrm{ml}$. Blood pressure was $100 / 70 \mathrm{mmHg}$. Therapy with $\delta$-penicillamine, $500 \mathrm{~g}$ four times daily, was instituted because of his intense colic and again promptly relieved him of pain. Renal biopsy was performed two days after admission, i.e., five days after the last occupational exposure to lead and exactly 48 hours after institution of therapy. The night after biopsy the patient developed paralysis of his right deltoid muscle. No cause other than lead poisoning could be found and muscle function has subsequently improved.

Case K.G., 47 years of age. He had been employed in different ship-breaking yards for the past four years. He suffered overt lead poisoning at least twice but was not confined to hospital either time. He was dismissed from one company because of lead poisoning but was soon employed in another ship-breaking yard. For a few months before his last admission to hospital he was busy cutting thick steel walls with heavy coatings of red lead in an old pocket-size 'dreadnought' of the first world war vintage. He was admitted to hospital because of pathological laboratory values during a routine control examination, the blood level indicating increased, and the urinary ALA dangerous lead absorption. He was free from clinical symptoms related to lead poisoning.

Case K.H., 66 years of age. This man had been employed at shipyards for more than 30 years and worked with reconstructions of naval vessels at the beginning of the second world war. In 1939 he suffered an illness suspected of being lead poisoning with muscle cramps, colicky pains, and vomiting. No laboratory examinations were carried out. By that time he was not burning steel himself (he became a burner at a later date) but was heavily exposed to smoke from welding torches. His occupation at shipyards and ship-breaking yards continued during the 1940 s and 1950 s. Since the beginning of the 1960s he had been occupied mainly with burning old ships' hulls. He worked rather sporadically and generally escaped the regular control tests. During the last four years he had been employed by the same company and found to have laboratory values indicating excessive lead absorption on at least three occasions. He kept away from work and from the regular control test when he felt ill. It is, therefore, impossible to assess his bouts of lead poisoning more exactly. He was admitted to hospital because of laboratory values indicating heavy lead exposure. Being old and taciturn he did not admit any physical discomfort. Occasional erythrocytes were found in the urinary sediment, but there were no other abnormal findings.

Case V.S., 46 years of age. This man had previously been a lumber-jack and a bulldozer engineer in Finland and in
Canada and had been employed in ship-breaking for the past five years. Since he was notoriously irresponsible and consumed large amounts of alcohol daily, he was absent from work for periods of up to one or two months. Lead in blood and urinary ALA had been elevated at several routine checks. However, he was not admitted to hospital because of lead poisoning until 1971; first he was admitted to a surgical department because of severe colic but was transferred to a medical department when pathological values for blood lead and urinary ALA were found. His blood lead was $80 \mu \mathrm{g} / 100 \mathrm{ml}$ and his urinary ALA $8 \cdot 17 \mathrm{mg} / 100 \mathrm{ml}$. Thus the blood lead indicated increased or excessive lead absorption while the urinary ALA level was clearly in the dangerous range. Other laboratory values are given in Tables 1 and 2 . A renal biopsy could not be performed because of low values for simplastin A, presumably due to liver damage. Renal clearances were measured prior to therapy with $\delta$ penicillamine. He responded favourably to treatment.

Case B.J., 55 years of age. He had been employed in shipbreaking since 1960 and was a skilled workman with no excessive alcohol intake and was generally cautious. Nevertheless he had been admitted to hospital 12 times because of lead poisoning, mostly with colic or gastric discomfort. He had had a unilateral nephrectomy in 1954 because of renal tuberculosis. Radiological examination revealed a compensatory enlargement of the remaining kidney with no anatomical abnormalities. A renal biopsy could not be performed in this one-kidney man. Laboratory values are given in Tables 1 and 2 , indicating excessive lead absorption. Renal clearances were measured prior to therapy with penicillamine. As during 10 earlier therapeutic courses, he responded promptly and favourably to treatment.

\section{Methods}

The renal clearance studies were carried out immediately after the patients were admitted to hospital, i.e., prior to therapy. Inulin and p-aminohippurate $(\mathrm{PAH})$ clearances were performed according to conventional methods, using continuous infusion techniques but without catheterization. The steady state level of PAH did not exceed $1.8 \mathrm{mg} / 100 \mathrm{ml}$. The clearances were determined during four 40-minute periods. Inulin and PAH were analysed by the methods of Hubbard and Loomis (1942) and Brun (1951), respectively. In two of the clearance periods ALA was determined in plasma and urine by ion-exchange chromatography (Jagenburg, 1974). Determination of ALA in urine was otherwise carried out by the method of Mauzerall and Granick (1956) modified by Haeger-Aronsen (1960). Amino acids were determined by ion-exchange chromatography (Spackman, Stein, and Moore, 1958) using a Beckman amino acid analyser model $120 \mathrm{C}$. The plasma was deproteinized by picric acid. Lead in blood and urine was determined by atomic absorption spectrophotometry (Selander and Cramér, $1968 \mathrm{a}$ and $\mathrm{b}$ ). These methods are checked routinely at least every four months against results from other laboratories in Sweden and Finland and are found to be highly reliable. Serum creatinine was determined in an Auto-Analyzer following the principle of the Jaffe reaction and uric acid by an uricase method (Praetorius and Poulsen, 1953).

Renal biopsies were performed using a Travenol dis- 
posable biopsy needle. The renal pelvis was visualized on a television screen after injection of 20 to $80 \mathrm{ml} 60 \%$ UrografinR (Schering-Werke). The needle was introduced lateral to the erector trunci musculature, generally in the lumbar trigonum, but in some instances distally or proximally to this, guided by the television screen projection. Renal biopsies were fixed in $2 \%$ glutaraldehyde and sent by air to North Carolina, USA. They were then post-fixed with osmic acid and embedded in Araldite and thick and thin sections were cut on a PorterBlum microtome. Thick sections were stained with toluidine blue and examined by light microscopy. Thin sections were stained with uranyl acetate and lead citrate and examined with a JEOLCO 100-B electron microscope.

Two of the biopsy specimens (V.M. and K.H.) were of sufficient size for a portion to be divided and embedded in paraffin. These sections were stained with haematoxylin-eosin, acid-fast for nuclear inclusions and Masson trichrome.

\section{Results}

Clinical and biochemical studies

Pertinent results on all seven workmen are summarized in Tables 1 to 3 . All showed signs of excessive or dangerous lead absorption as revealed by high blood lead concentration and high urinary lead excretion. The urinary excretion of ALA ranged from 45 to $187 \mathrm{mg} / 24$ hours, and the concentration of ALA in plasma from 1.1 to 10.8 $\mathrm{mmol} / \mathrm{l}$. The calculated renal ALA clearance was close to the observed inulin clearance value. The glomerular filtration rate as revealed by the inulin clearance was normal or in some of the subjects moderately reduced. In B.J., who had previously undergone unilateral nephrectomy, the inulin clearance was $78 \mathrm{ml} / \mathrm{min}$. The serum uric acid was normal (reference value 2.6-7.5 $\mathrm{g} / 100 \mathrm{ml}$ ) except in case A.C., who had a concentration of $9 \cdot 2 \mathrm{mg} / 100 \mathrm{ml}$. Total renal blood flow appeared to be more or less increased in all cases as revealed by the high PAH clearance in relation to the glomerular filtration rate. The filtration fraction was as a mean $0 \cdot 14$ (range $0 \cdot 11-0 \cdot 18$ ) which is considerably lower than in healthy subjects (mean $0 \cdot 20$, range $0 \cdot 17-0 \cdot 23$ ). The PAH clearances were determined at PAH concentrations in serum of $1.4-1.8 \mathrm{mg} / 100 \mathrm{ml}$. Tests for albuminuria and glycosuria were negative. Urinary sediment was generally normal but on a few occasions a slight increase in the leucocyte count was observed. The renal tubular reabsorption of amino acids was normal (Table 3). The mean concentration of proline, valine, tyrosine, and phenylalanine was significantly lower $(P<0.01)$ in those with abnormal lead absorption than in the controls.

\section{Renal biopsies}

Each of the biopsy specimens contained renal cortical tissue with numerous tubules and varying numbers of glomeruli. The glomeruli were unremarkable except for swelling and distortion of organelles in the cytoplasm and foot processes of epithelial cells (Fig. 1). There was no fusion of foot processes and basement membranes were not thickened in any of the biopsies. The most remarkable ultrastructural findings were in proximal tubular lining cells. Three types of changes were

TABLE 3

Plasma Concentration and Urinary Excretion of Amino Acids in Subjects with Excessive or Dangeous Lead Absorption, and in Controls not exposed to Lead

\begin{tabular}{|c|c|c|c|c|c|c|c|}
\hline & & \multicolumn{2}{|c|}{$\begin{array}{c}\text { Plasma concentration } \\
(\mu \mathrm{mol} / \mathrm{l})\end{array}$} & \multicolumn{4}{|c|}{$\begin{array}{c}\text { Urinary excretion } \\
\text { ( } \% \text { of filtered amount })\end{array}$} \\
\hline & & $\begin{array}{c}\text { Lead intox. } \\
n=7 \\
M \pm S D\end{array}$ & $\begin{array}{c}\text { Controls }^{1} \\
n=16 \\
M \pm S D\end{array}$ & \multicolumn{2}{|c|}{$\begin{array}{c}\text { Lead intox. } \\
n=7\end{array}$} & \multicolumn{2}{|c|}{$\begin{array}{c}\text { Controls }^{2} \\
n=5\end{array}$} \\
\hline $\begin{array}{l}\text { Threonine } \\
\text { Serine } \\
\text { Proline }\end{array}$ & $\begin{array}{l}\ldots \\
\cdots \\
\cdots \\
\ldots \\
\cdots \\
\cdots \\
\ldots \\
\cdots \\
\cdots \\
\cdots \\
\cdots\end{array}$ & $\begin{array}{c}143 \pm 44 \\
131 \pm 20 \\
124 \pm 22^{3} \\
86 \pm 28 \\
236 \pm 54 \\
318 \pm 58 \\
191 \pm 25^{3} \\
32 \pm 7 \\
63 \pm 11 \\
117 \pm 21 \\
56 \pm 9^{3} \\
46 \pm 10^{3}\end{array}$ & $\begin{array}{r}144 \pm 29 \\
150 \pm 33 \\
205 \pm 71 \\
75 \pm 21 \\
232 \pm 47 \\
348 \pm 53 \\
246 \pm 55 \\
30 \pm 10 \\
67 \pm 18 \\
132 \pm 30 \\
67 \pm 10 \\
59 \pm 10\end{array}$ & $\begin{array}{l}1.2 \\
2.4 \\
0.5 \\
3.4 \\
0.6 \\
0.2\end{array}$ & $\begin{array}{r}0 \cdot 7-2 \cdot 1 \\
2 \cdot 0-3 \cdot 2 \\
<0 \cdot 1 \\
0 \cdot 2-1 \cdot 4 \\
1 \cdot 3-7 \cdot 2 \\
0 \cdot 2-1 \cdot 3 \\
0 \cdot 1-0 \cdot 4 \\
<0 \cdot 4 \\
<0 \cdot 4 \\
0 \cdot 2-0 \cdot 4 \\
0 \cdot 1-2 \cdot 2 \\
0 \cdot 5-0.9\end{array}$ & $\begin{array}{l}3.2 \\
0.3 \\
0.1 \\
\\
0.2 \\
0.9 \\
0.4\end{array}$ & $\begin{array}{r}0.4-1 \cdot 5 \\
0 \cdot 6-3 \cdot 1 \\
<0 \cdot 1 \\
<0 \cdot 5 \\
2 \cdot 1-5 \cdot 3 \\
0 \cdot 1-0 \cdot 6 \\
0 \cdot 1-0 \cdot 2 \\
<0.2 \\
<0 \cdot 2 \\
0 \cdot 1-0.3 \\
0 \cdot 4-1 \cdot 7 \\
0 \cdot 2-0.7\end{array}$ \\
\hline
\end{tabular}

116 healthy male subjects $21-53$ years of age

25 healthy male subjects $22-53$ years of age

'Difference between patient group and controls significant $(P<0.01)$ 


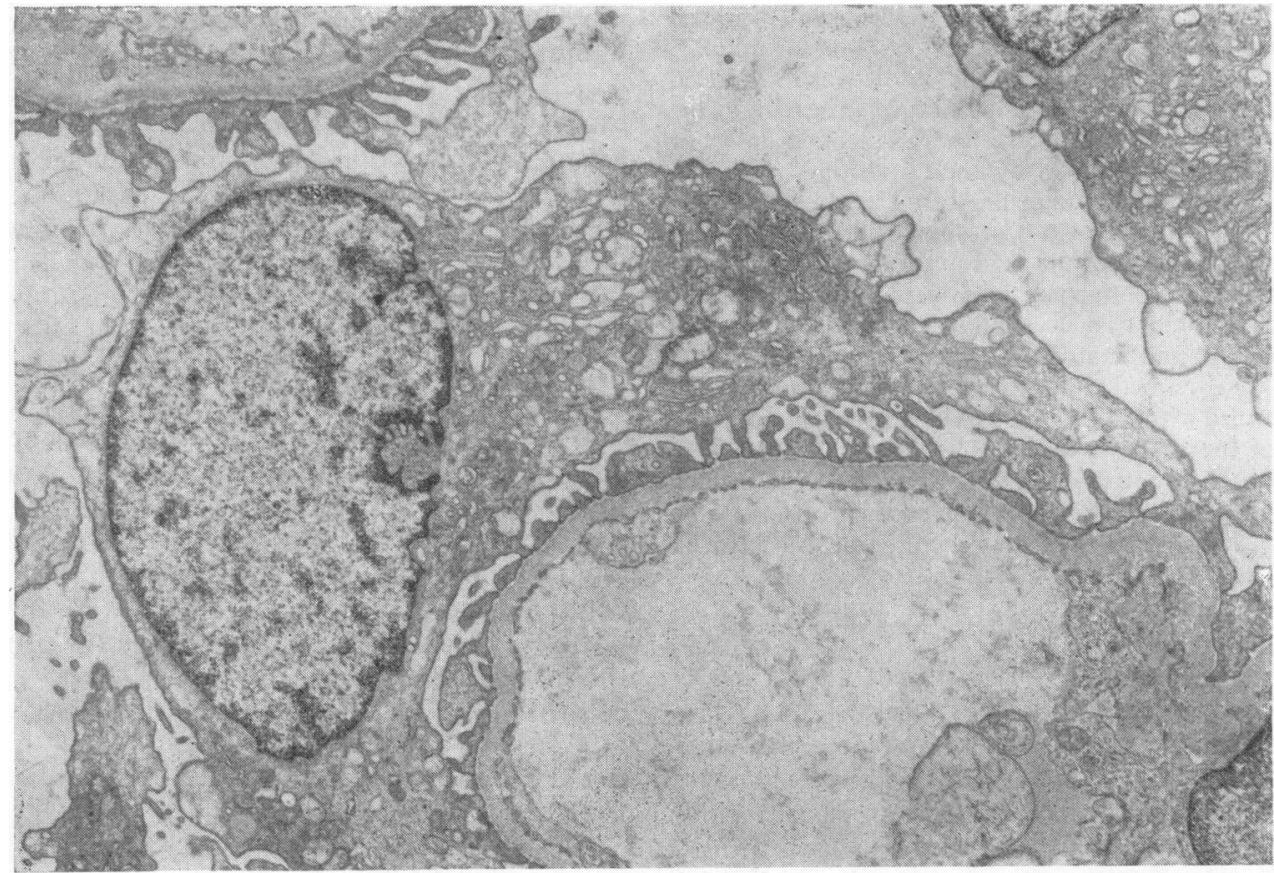

FIG. 1. Capillary in glomerulus from renal biopsy of lead industry worker (V.M.). Cytoplasmic organelles including mitochondria and endoplasmic reticulum of epithelial cells are swollen. Foot processes and basement membrane are normal. $\times 6500$

found in nuclei: (1) lead-induced nuclear inclusion bodies, (2) clumped granular chromatin, and (3) pseudoinclusions or nuclear invagination of cytoplasmic contents. Figure 2 shows a typical densestaining lead-induced inclusion body. These bodies are identical with those previously observed in necropsies and biopsied kidneys of humans with excessive lead exposure (Galle and Morel-Maroger, 1965) and they are identical with nuclear inclusion bodies induced in experimental animals by the administration of lead (Goyer, 1971a). These bodies were found in only two biopsies (J.V. and V.M.), i.e., from those with lead exposure of less than one year.

A second form of nuclear body was found in three of the biopsies and consisted of clumped granular chromatin (Fig. 3a) independent of the nucleolus. In one instance a granular chromatin band was found extending from the nucleolus to the nuclear membrane (Fig. 3b).

A third nuclear change consisted of invagination of nuclear membranes sometimes forming isolated intranuclear bodies lined by a single membrane and containing degenerating cytoplasmic organelles. These bodies may be regarded as 'psendoinclusions' and are distinguished morphologically from the two types of nuclear bodies in Figs 2 and 3 by invagination of nuclear membrane (Richter, Kress, and Cornwall, 1968).
Mitochondria in all tubular lining cells of each of the biopsies showed some degree of swelling and distortion of cristae (Fig. 4). Some of the mitor chondria are transected by cristae, suggesting division of the inner compartment perhaps leading to cleavage or budding. Endoplasmic reticulum was swollen and in some cells appeared to be increased in amount. Lysosomes were numerous in some cells, particularly in biopsies from the two workmen with less than one year's work history. Lysosomes in some cells contained dense bodies of varying size (Fig. 5).

The light microscopic examination of either paraffin-embedded material or thick Araldite sections showed abnormal amounts of peritubular fibrous tissue in the biopsies from the three workers who had been occupationally exposed to lead for the longest periods of time in contrast to workmen with excessive lead exposure for less than one year (Figs. 6a and b). The pattern of fibrosis was evenly diffuse in biopsies from A.C. and K.G. but pronounced focal scarring was present as well in the biopsy from K.H. Blood vessels were not remarkably changed in any of the biopsy specimens.

\section{Discussion}

The present study comprises only seven patients 


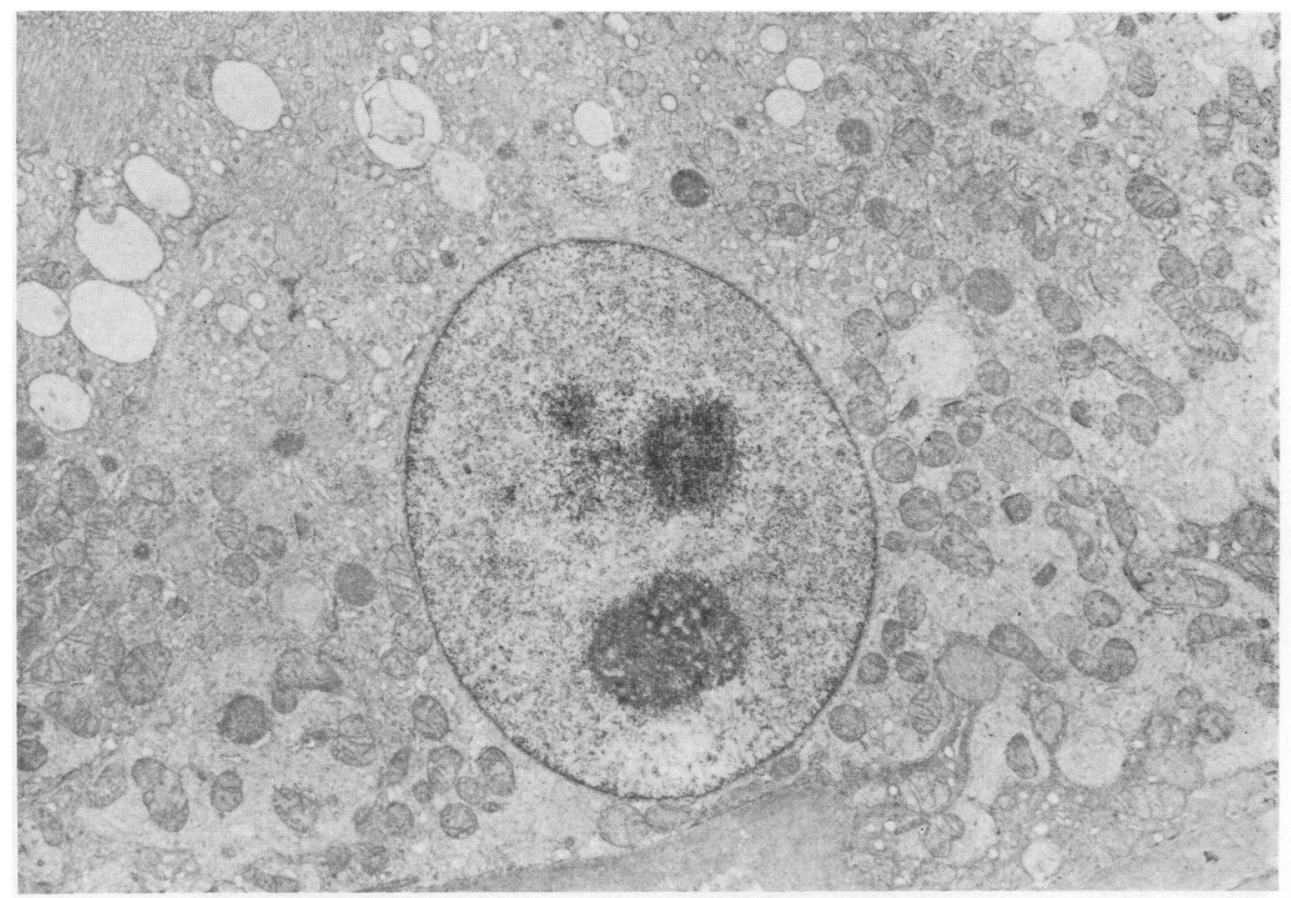

(a)

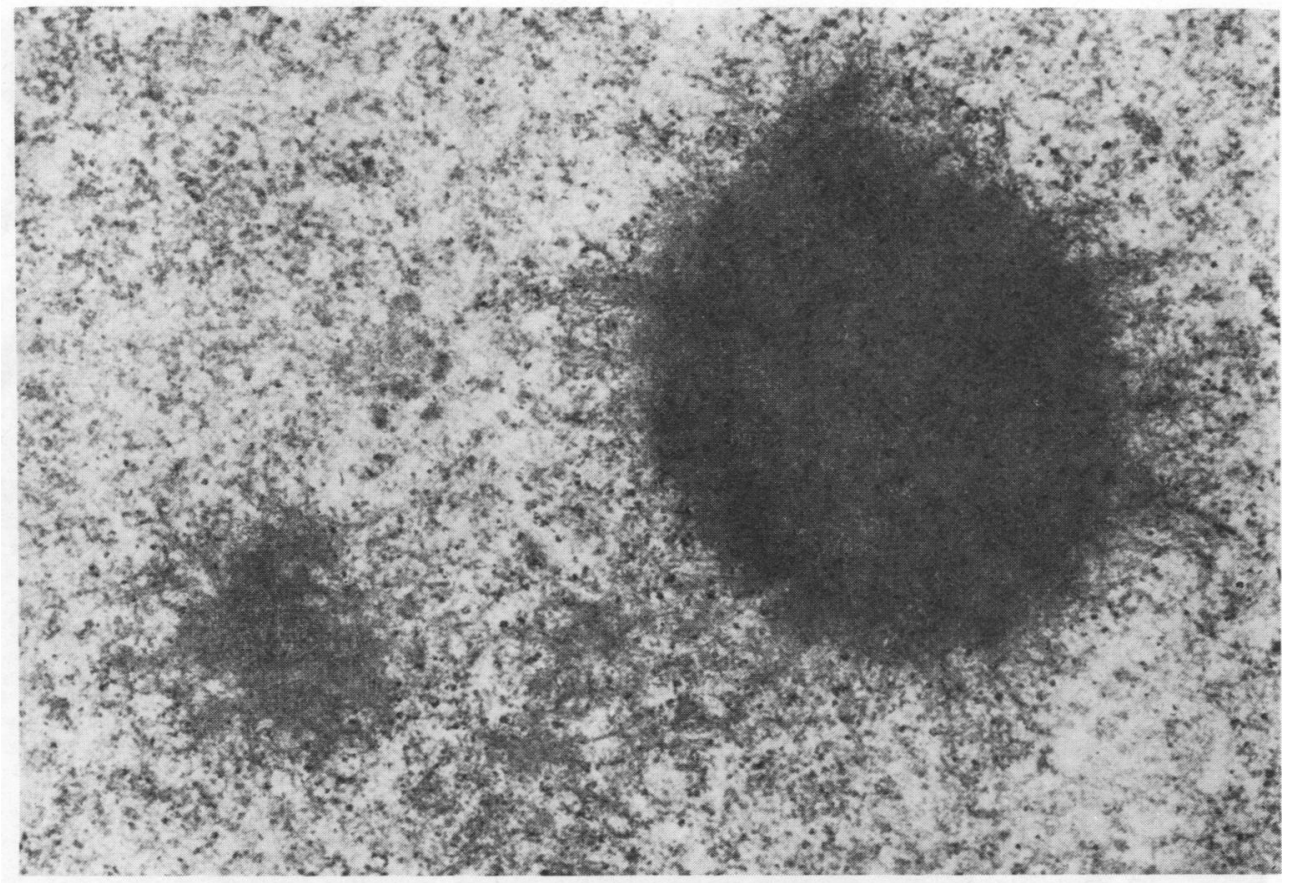
(b)

FIG. 2. (a) Intranuclear inclusion bodies in nucleus of proximal tubular lining cell of workman with less than one year's exposure to lead (V.M.). The inclusion bodies are above the nucleolus, $\times 6500$; (b) Greater magnification of lead-induced inclusion bodies shown in $(a)$. The central portions of the bodies are dense and the margins are fibrillary. $\times 52500$ 


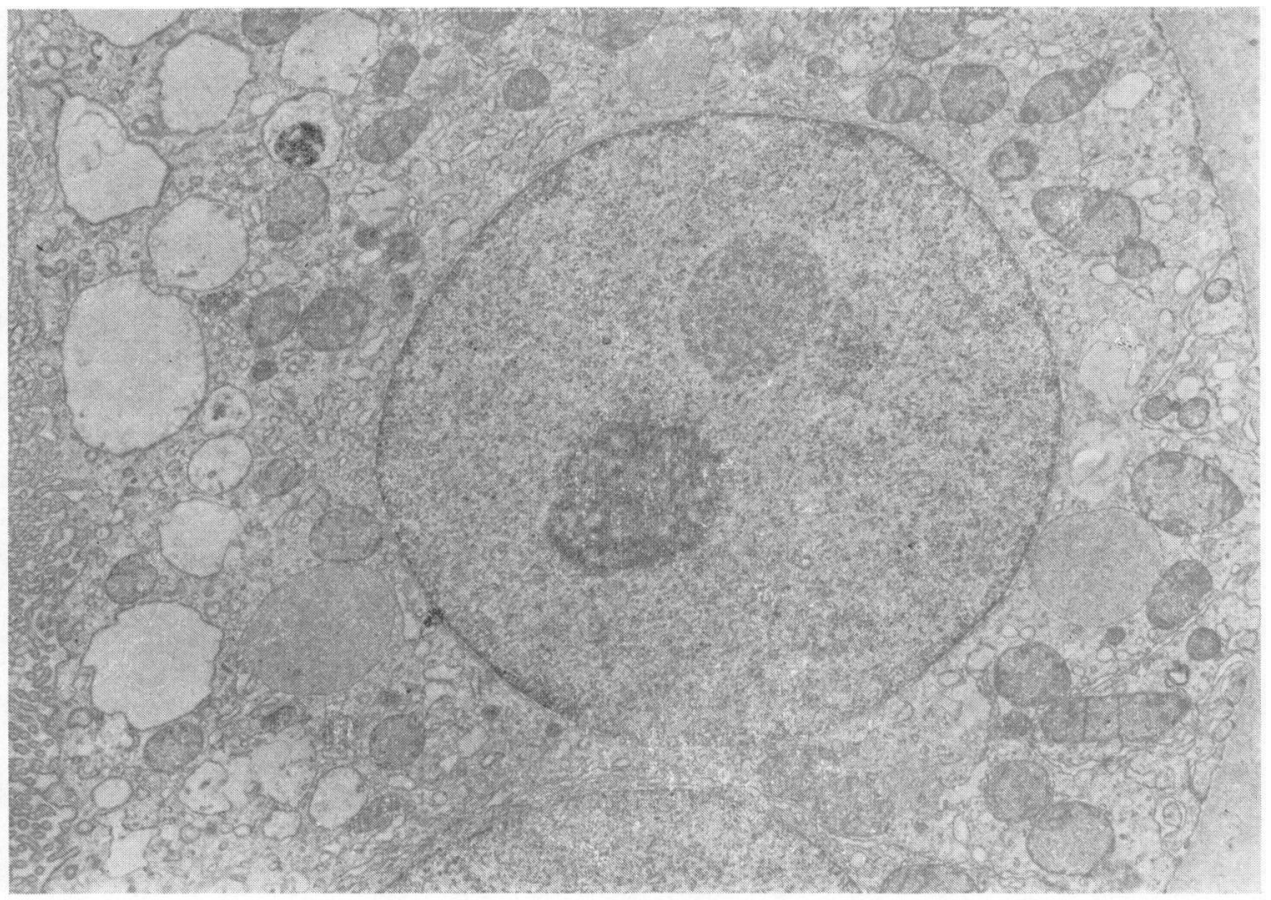

(a)

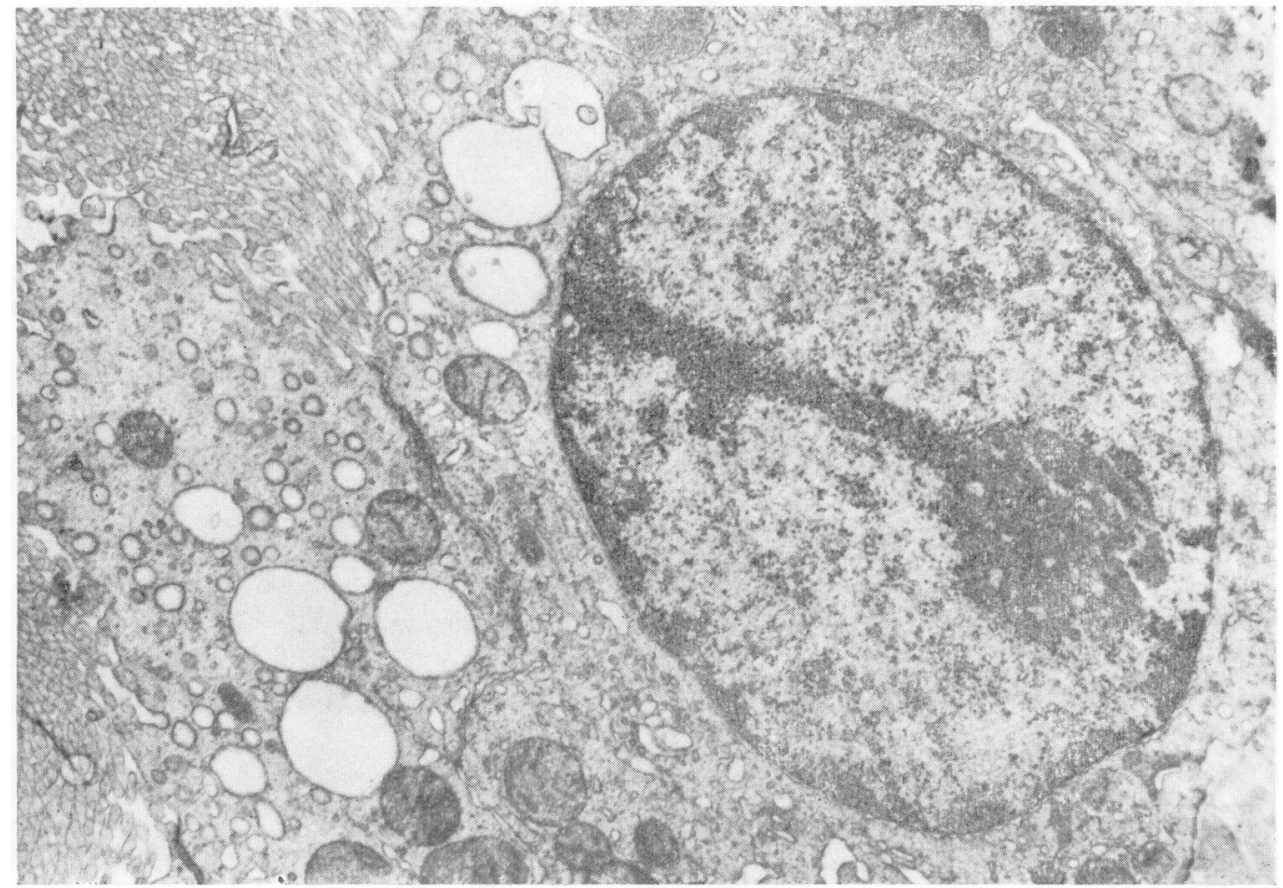

(b)

FIG. 3. (a) Renal tubular cell nucleus from lead worker (A.C.) showing granular chromatin body, $\times 7800 ;(b)$ Nucleus from renal biopsy from another worker (K.H.) showing a cord of granular chromatin connecting nucleolus with nuclear membrane. $\times 18000$ 


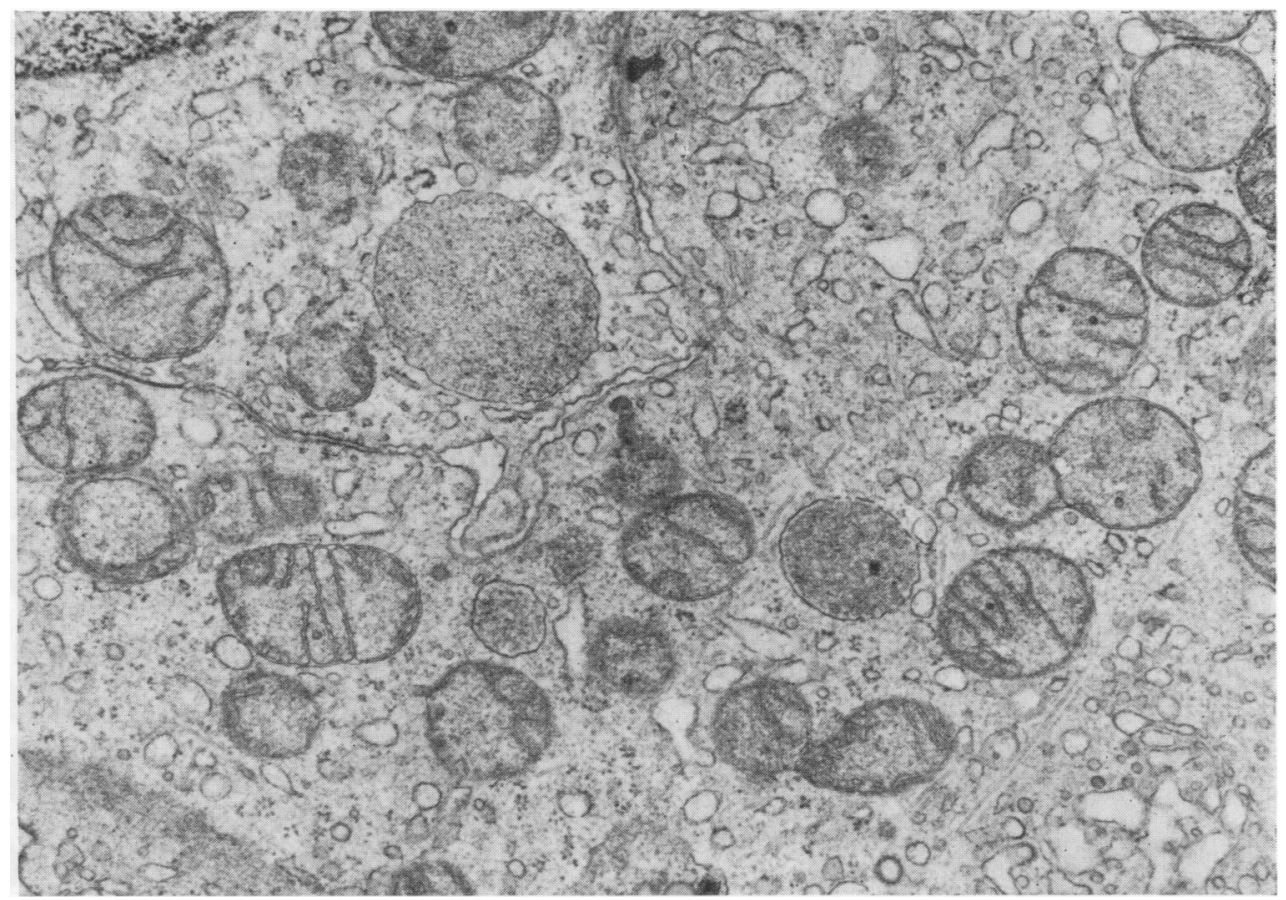

FIG. 4. Mitochondria in renal tubular lining cell from lead worker (V.M.) showing bizarre mitochondria. In some mitochondria the inner membrane divides the inner compartment, resulting in actual budding or cleavage. Endoplasmic reticulum is swollen and increased in amount. $\times 19000$

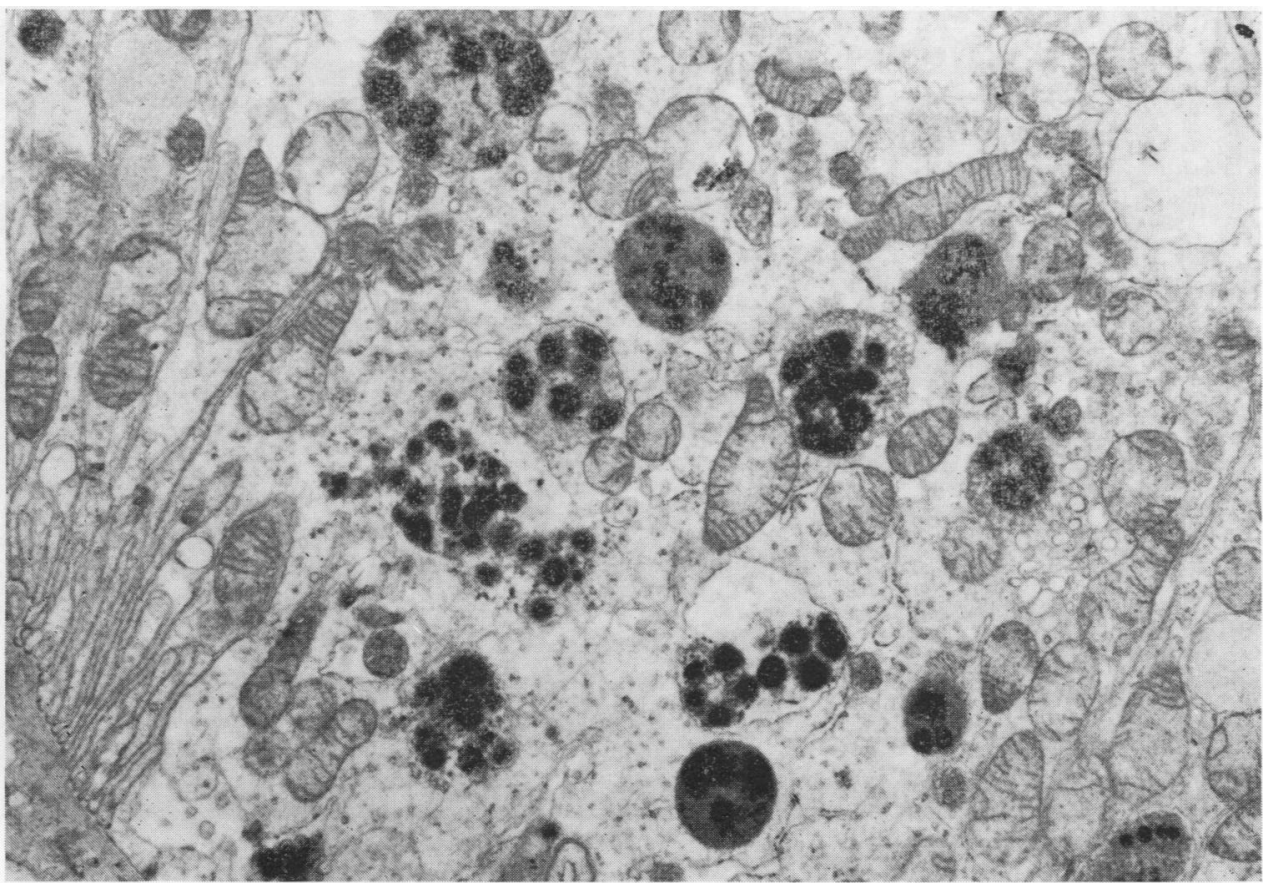

FIG. 5. Subcellular components of proximal tubular lining from lead industry worker (V.M.). Lysosomes are increased in number and contain dense bodies. Poorly defined vesicular structures 


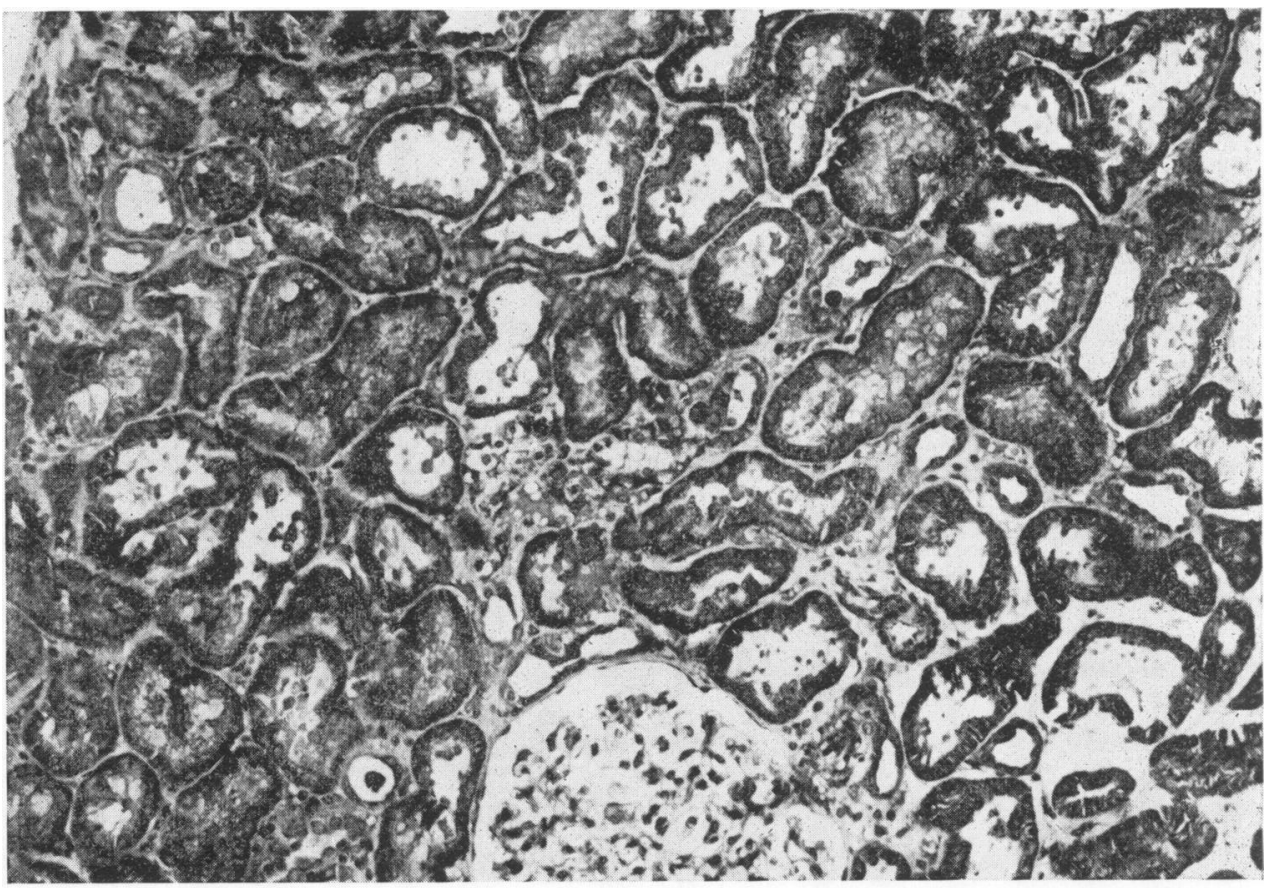

(a)

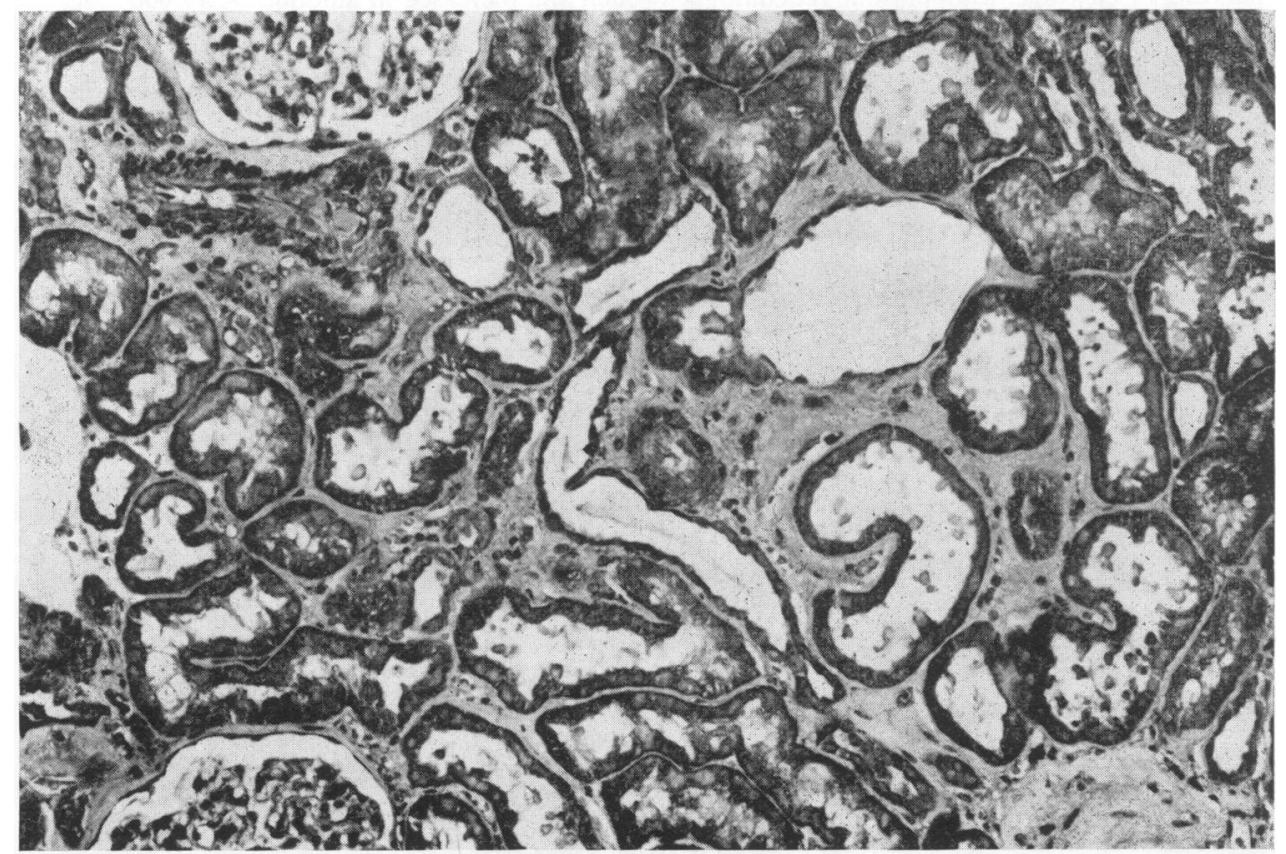

(b)

FIG. 6. The extent and pattern of peritubular and interstitial fibrosis is compared in the renal cortex from a workman with three months' occupational exposure to lead $(a)$ and 20 years' work history $(b)$. 
(five renal biopsies) but there is an apparent contrast in findings between those workmen with occupational exposure to lead for less than one year and those with more chronic exposure. The renal biopsies from the two workmen with relatively short exposure to lead (J.V., six weeks and V.M., eight months) contained typical lead-induced nuclear inclusion bodies in proximal tubular lining cells whereas the three other workmen with exposure periods extending from four years to more than 12 years did not contain any such inclusions. Renal biopsies from workmen with longer periods of lead exposure had a diffuse interstitial or peritubular fibrosis. On the other hand, workers with shorter periods of lead exposure and lead-induced nuclear inclusion bodies had a greater urinary excretion of lead.

\section{Nuclear inclusion bodies}

The ultrastructural characteristics of these bodies are sufficiently distinct to be able to differentiate them from other forms of nuclear bodies such as granular chromatin bodies, viral inclusion bodies or even inclusion bodies induced by other metals (e.g., bismuth). They have been shown from experimental studies to be composed of a lead-protein complex (Goyer, May, Cates, and Krigman, 1970), and it has been suggested that the binding of lead that occurs in the inclusion body serves as an adaptive or detoxifying mechanism during transcellular transport of lead (Goyer, 1971b). In the course of excretion of lead from capillaries to bile by hepatic cells or by transtubular flow in renal tubular lining cells a portion of the lead enters the nucleus where it becomes bound into a lead-protein complex and is no longer diffusible. This mechanism has the effect of maintaining a relatively low cytoplasmic concentration of lead, thereby reducing the toxic effects of lead on sensitive cellular functions such as mitochondrial respiration and protein synthesis. Indirect support for this hypothesis is found in experimental studies of the relationship of the formation of intranuclear inclusion bodies and other renal effects of lead. When groups of rats are given different concentrations of lead in their drinking water, intranuclear inclusion bodies are observed at a lower dose than in any other renal effect of lead, in fact, at a lower dose of lead than that which produces signs and symptoms of lead toxicity (Goyer et al., 1970b).

The incidence of intranuclear inclusion bodies in renal biopsies of workmen with exposure to lead can be compared with a similar report of renal biopsies by Galle and Morel-Maroger (1965) and Richet et al. (1966), in which some form of nuclear body was found in 17 of the 23 renal biopsies. In the study from France the renal biopsies were performed at irregular intervals (from three weeks up to seven years) after the last lead exposure and sometimes even after several courses of therapy with chelating agents, either CaEDTA, CaDPTA or penicillamine (Richet and Albahary, personal communication). Nevertheless, the typical fibrillary leadinduced nuclear inclusion was found in only one workman with a short history of occupational exposure to lead (three months). This suggested to the authors also that this form of nuclear inclusion is related to short-term exposure to lead whereas the granular chromatin bodies are formed after more chronic occupational lead exposure (more than three years) (Galle and Morel-Maroger, 1965). Such granular chromatin bodies are not a specific effect of lead but are found in many other pathological conditions. They may be related to cellular hyperactivity (Bouteille, Kalifat, and Delarue, 1967).

Relationship of absence of lead-induced inclusion bodies and chelation therapy

It must be considered whether chelation therapy might be responsible for the absence of leadinduced inclusion bodies in the older workman. Present knowledge regarding the effect of chelating agents on renal tubular cells in lead poisoning does not permit a definitive conclusion. However, treatment of lead-poisoned rats with parenteral EDTA removes lead-induced inclusion bodies from renal tubular lining cells (Goyer, Wilson, and Cates 1974). Whether continued exposure to excessive lead results in reformation of the bodies is not known. One of the workmen in the group under study (A.C.) was given chelation therapy 48 hours prior to renal biopsy. This might explain the absence of inclusion bodies in this man but the ultrastructure of his renal tubular lining cells did not differ significantly from that of the two other older workmen without recent chelation therapy. Case K.H., however, had never had any chelation therapy, but showed no inclusions. The presence or absence of lead-containing inclusion bodies in workmen with different periods of exposure to lead is of particular interest in this study because of the possible role of these bodies in the renal excretion of lead.

\section{Renal excretion of lead}

The kidney is presumed to excrete lead by two routes, glomerular filtration and transtubular flow or excretion (Vostal and Heller, 1968). The relative importance of the two routes is uncertain but the formation of lead-containing inclusion bodies suggests that with elevated blood lead levels, transtubular flow may assume a greater importance.

The trend to lesser urinary excretion of lead in older workers may be explained in several ways. The absence of intranuclear inclusion body formation may reflect a decrease in the level of transtubular transport or tubular excretion of lead. Without precise information regarding levels of exposure it is 
difficult to be certain that the two groups of workmen received comparable levels of exposure.

Another factor that may lower the number of cells with lead-containing inclusion bodies is a reduced life span of tubular lining cells. Experimental studies in lead-poisoned rats have shown an increase in renal cell turnover (Choie and Richter, 1972). The newly formed cells may be too short-lived to form inclusion bodies. Relevant to this suggestion is the finding that lead-induced neoplasms in rats contain less lead than adjacent non-neoplastic renal tissue (Mao and Molner 1967).

Alternatively, the lesser urinary excretion of lead in the more chronically exposed workmen may reflect an increase in other routes of lead excretion, particularly faecal excretion resulting from an increase in hepatobiliary excretion.

\begin{abstract}
Alcohol and lead
Since all five men included in the present study had liberal alcohol drinking habits, a possible influence of alcohol ingestion on the severity of the renal effects of lead must be considered. A certain synergism between lead and alcohol has been observed. Classical examples of the peril of lead in connection with alcohol are given by Sir George Baker (Editorial, 1968) and by Tanquerel des Planches (1839) in his extensive and brilliant study of Paris housepainters. The latter showed maximum lead colic on Tuesdays, which Tanquerel des Planches explained by the fact that they were paid on Mondays and celebrated this by an alcoholic bout on Monday evening. A higher incidence of clinical lead poisoning in drinkers than in non-drinkers was pointed out by Oliver (1914) and other workers, and on the biochemical level by Cramér (1966).

The cellular basis for the possible synergism between alcohol and lead is as yet imperfectly understood. Alcohol as well as lead inhibits ALAdehydratase activity in vitro (Moore, 1972; Hernberg, 1972) and other possible synergisms between these two toxins at the level of the mitochondrion have been reviewed by Goyer (1971a). It is unlikely that alcohol in itself is responsible for the renal pathology as observed in these workmen, although experimentally induced lead toxicity is enhanced by simultaneous ingestion of alcohol (Mahaffey, Goyer, and Wilson, 1973).
\end{abstract}

Plasma concentration of urinary excretion of ALA and other amino acids

ALA-dehydratase is strongly inhibited by lead (de Bruin and Hoolboom, 1967; Nakao, Wada and Yano, 1968), which explains the augmented plasma ALA level observed in lead intoxication (Druyan, Haeger-Aronsen, von Studnitz, and Waldenström, 1965). The increased urinary excretion of ALA is thus at least partly due to an overflow mechanism.
A reduced renal tubular reabsorption, as observed for other amino acids, has been considered to be a contributing factor to the abnormal ALA excretion (Druyan et al., 1965). However, the present results, obtained by a highly specific method, show that the renal ALA clearance is similar to the glomerular filtration rate at plasma ALA concentrations ranging from 1.1 to $10.8 \mu \mathrm{mol} / 1$. Furthermore, the plasma ALA concentration in healthy subjects was found to be considerably lower than reported by Druyan $e t$ al. (1965), which indicates that ALA also normally is not significantly reabsorbed in the renal tubules. In patient A.C., who had severe signs and symptoms of dangerous lead absorption, the plasma ALA was considerably higher than in the other patients. A moderately impaired renal function was a contributing factor to the high plasma ALA level in this patient. Other changes in the plasma amino acid pattern were also observed. Thus the levels of proline, valine, tyrosine, and phenylalanine were significantly lower in the lead-intoxicated workers than in healthy male subjects of similar age. These differences are not necessarily caused by the lead intoxication but might be due to nutritional differences. A low protein intake in children is known to reduce the levels of the essential amino acids including tyrosine (Snyderman et al., 1968) whereas in adults the changes are less pronounced (Adibi, 1968). No explanation for the low proline can be offered. In lead-intoxicated rats the only change in the plasma amino acids was an increase in the glycine level (Goyer, Leonard, Bream, and Irons, 1970a) which was not observed in the present study. In experimental lead intoxication in animals (von Studnitz and Haeger-Aronsen, 1962; Sun, Goyer, Mellies, and Yin, 1966; Goyer et al., 1970a) and in accidental lead poisoning in childhood (Wilson, Thomson, and Dent, 1953; Chisolm, 1962) marked amino aciduria and other renal tubular defects have been observed. The lead workers studied by us showed a normal tubular reabsorption of amino acids. This is in agreement with other studies showing that human adults, even when heavily exposed to lead, generally have little or no excessive aminoaciduria (Clarkson and Kench, 1956; Goyer, Tsuchiya, Leonard, and Kahyo, 1972).

\section{PAH clearance and filtration fraction}

As revealed from the PAH clearance determinations, six of the seven patients in the present study had an increased relative renal plasma flow. This is contradictory to the results obtained by Lilis et al. (1967). They reported a reduction of the effective plasma flow in patients with chronic lead poisoning. These authors, however, used less accurate methods for determination of filtration rate and renal plasma flow. There was no correlation between the filtration fraction and the length of the lead exposure in 
the present study. The lowest filtration fraction, however, was seen in the patient who was most heavily intoxicated and who had a moderate anaemia. The anaemia per se will lower the filtration fraction but not to the extent observed in the patient. Low filtration fractions are seen also in glomerulonephritis (Bradley et al., 1950; Earle, 1968) and in systemic lupus erythematosus (Hood, Attman, Ahlmén, and Jagenburg, 1971). Renal hyperaemia thus seems to be a common pattern of response to different processes affecting glomeruli. The mechanism is not yet clear.

\section{Stages of lead-induced nephropathy}

Whether excessive exposure to lead results in a form of chronic nephropathy has long been debated. A sequence of histological changes extending from the occurrence of lead-induced intranuclear inclusion bodies to diffuse interstitial fibrosis and renal failure has been described in animal studies by Goyer (1971a), and it was concluded that a particular lead dose $\times$ time relationship might result in a form of chronic nephropathy.

This study of humans with prolonged lead exposure suggests that there may be two or three stages in the response of the human kidney to chronic lead exposure. In an early phase, lasting less than one year, the proximal renal tubular cells form nuclear inclusion bodies similar to those found in experimental lead poisoning in animals. During this phase there is also a relatively high urinary output of lead but no impairment of renal function. The ultrastructural changes are probably reversible. In a second phase, after four or more years of exposure, the proximal tubular cells apparently have decreased their ability to form nuclear inclusions, and the kidneys excrete less lead and morphologically have a moderate degree of interstitial fibrosis. This phase is not characterized by any gross impairment of renal function but it is doubtful whether the morphological changes are completely reversible.

A critical question is whether a third phase of lead nephropathy with frank renal failure may occur after severe prolonged lead exposure. The evidence from clinical studies suggests that lead may induce renal failure but review and follow-up of several hundreds of persons with exposure to lead in the shipbreaking occupation or storage battery manufacture over the past 12 years has not detected a single case (personal study of one of the authors, K.C.). However, two of the workmen in this study (A.C. and V.S.) had a moderate reduction in glomerular filtration rate. Whether they will develop frank renal failure in the future is uncertain. A number of cases of chronic interstitial nephritis with renal failure were observed (Lane, 1949) among a population of workmen who were heavily exposed to lead (probably over $0.5 \mathrm{mg} / \mathrm{m}^{3}$ ) prior to the institution of an adequate control programme. Subsequent studies by Dingwall-Fordyce and Lane (1963) and Malcolm (1970) showed that in a large group who had worked under controlled conditions since 1927 there were no cases of chronic interstitial nephritis with renal failure. In France, Richet $e t$ al. (1964) looked upon chronic renal disease and clinical renal failure as more or less inevitable sequelae to prolonged lead exposure. Lilis et al. (1967) in Romania report renal insufficiency in 17 of 102 cases of chronic lead poisoning. Radosevic, Saric, Beritic, and Knezevic (1961) in Yugoslavia performed an extensive study of renal function in 53 lead-exposed patients, 45 men and 8 women. Fortyfour were exposed in their occupation, while nine had used lead-glazed pottery, presumably, although not stated in the paper, for storage of wine. This material comprises 27 patients with blood levels higher than $100 \mu \mathrm{g} / 100 \mathrm{ml}$ (5 higher than $200 \mu \mathrm{g} / 100$ $\mathrm{ml}$ ) and the time of lead exposure is given in a separate table but not put in relation to the clinical findings. Although exposure to lead must have been considerable, renal failure was found in only two cases. In several cases transient urine abnormalities were found in connection with acute poisoning and treatment. The authors stress that 'the timing of individual tests is of paramount importance, as some lesions are subject to changes in the natural course of lead poisoning, and unless this is borne in mind, apparently contradictory results may be obtained'.

It can be concluded that the present study does demonstrate that the pathogenesis of chronic lead nephropathy is a continuum of morphological and functional change that can be divided into at least two stages. A third stage characterized by renal failure is suggested by past literature and experimental study but this stage was not demonstrated in this study.

This study was supported in part by US Public Health Service grant ES-00481 and by grant B72-61P-3649-01 from the Swedish Medical Research Council.

\section{References}

Adibi, S. A. (1968). Influence of dietary deprivations on plasma concentration of free amino acids of man. Journal of Applied Physiology, 25, 52-57.

Bouteille, M., Kalifat, S. R., and Delarue, J. (1967). Ultrastructural variations of nuclear bodies in human diseases. Journal of Ultrastructure Research, 19, 474-486.

Bradley, S. E., Bradley, G. P., Tyson, C. J., Curry, J. J., and Blake, W. D. (1950). Renal function in renal diseases. American Journal of Medicine, 9, 766-798.

Brun, C. (1951). A rapid method for the determination of para-aminohippuric acid in kidney function tests. Journal of Laboratory and Clinical Medicine, 37, 955-958.

Chisolm, J. J. (1962). Aminoaciduria as a manifestation of renal tubular injury in lead intoxication and a comparison with patterns of aminoaciduria seen in other diseases. Journal of Pediatrics, 60, 1-17. 
Choie, D. D. and Richter, G. W. (1972). Cell proliferation in rat kidney induced by lead acetate and effects of uninephrectomy on the proliferation. American Journal of Pathology, 66, 265-275.

Clarkson, T. W. and Kench, J. E. (1956). Urinary excretion of amino acids by men absorbing heavy metals. Biochemical Journal, 62, 361-372.

Cramér, K. (1966). Predisposing factors for lead poisoning. Acta Medica Scandinavica, Supplement 445, 56-59.

De Bruin, A. and Hoolboom, H. (1967). Early signs of lead exposure. A comparative study of laboratory tests. British Journal of Industrial Medicine, 27, 203-212.

Dingwall-Fordyce, I. and Lane, R. E. (1963). A follow-up study of lead workers. British Journal of Industrial Medicine, 20, 313-315.

Druyan, R., Haeger-Aronsen, B., von Studnitz, W., and Waldenström, J. (1965). Renal mechanism for excretion of porphyrin precursors in patients with acute intermittent porphyria and chronic lead poisoning. Blood, 26, 181-189.

Earle, D. P. (1968). Physiologic abnormalities in acute glomerulonephritis. In Acute Glomerulonephritis, Proc. 17th Annual Conf. on the Kidney, edited by J. Metcoff, p. 301. Churchill, London.

Editorial (1968). Sir George Baker (1722-1809). Discoverer of the pathogenesis of Devonshire colic. Journal of the American Medical Association, 204, 541.

Galle, P. and Morel-Maroger, L. (1965). Les lésions rénales du saturnisme humain et expérimental. Nephron, 2, 273-286.

Goyer, R. A. (1968). The renal tubule in lead poisoning. I. Mitochondrial swelling and aminoaciduria. Laboratory Investigation, 19, 71-77.

- (1971a). Lead and the kidney. Current Topics in Pathology, 55, 147-176.

- (1971b). Lead toxicity: a problem in environmental pathology. American Journal of Pathology, 64, 167-182.

- , Krall, A., and Kimball, J. P. (1968). The renal tubule in lead poisoning. II. In vitro studies of mitochondrial structure and function. Laboratory Investigation, 19, 7883.

—_ Leonard, D. L., Bream, P. R., and Irons, T. G. (1970a). Aminoaciduria in experimental lead poisoning. Proceedings of the Society for Experimental Biology and Medicine, 135, 767-771.

- - - Moore, J. F., Rhyne, B., and Krigman, M. R. (1970b) Lead dosage and the role of the intranuclear inclusion body. Archives of Environmental Health, 20, 705-711

—, May, P, Cates, M. M., and Krigman, M. R. (1970). Lead and protein content of isolated intranuclear inclusion bodies from kidneys of lead-poisoned rats. Laboratory Investigation, 22, 245-251.

- Tsuchiya, K., Leonard, D. L., and Kahyo, H. (1972) Aminoaciduria in Japanese workers in the lead and cadmium industries. American Journal of Clinical Pathology, 57, 635-642.

Goyer, R. A., Wilson, M. H., and Cates, M. (1974). Effect of EDTA on lead induced inclusion bodies and tissue lead content of ead toxic rats. Federal Proceedings, 33, 227 (Abstract).

Haeger-Aronsen, B. (1960). Studies on urinary excretion of $\delta$-aminolaevulic acid and other haem precursors in lead workers and lead-intoxicated rabbits. Scandinavian Journal of Clinical and Laboratory Investigation, 12, Supplement 47, 1-128.

Hernberg, S. (1972). Effect of lead on $\delta$-aminolaevulinic acid dehydratase, a selective review. Pracovni Lékařstvi, 24, 77-83.

Hood, B., Attman, P. O., Ahlmén, J., and Jagenburg, R. (1971). Renal hemodynamics and limitations of creatinine clearance in determining filtration rate in glomerular disease. Scandinavian Journal of Urology and Nephrology, 5, 154-161.

Hubbard, R. S. and Loomis, T. A. (1942). The determination of inulin. Journal of Biological Chemistry, 145, 641645.

Jagenburg, R. (1974). Determination of $\delta$-aminolaevulinic acid by ion-exchange chromatography. Scandinavian Journal of Laboratory and Clinical Investigation (In press).

Lane, R. E. (1949). The care of the lead worker. British Journal of Industrial Medicine, 6, 125-143.

, Hunter, D., Malcolm, D., Williams, M. K., Hudson, T. G. F., Browne, R. C., McCallum, R. I., Thompson, A. R., de Kretser, A. J., Zielhuis, R. L., Cramér, K., Barry, P. S. I., Goldberg, A., Beritic, T., Vigliani, E. C., Truhaut, R., Kehoe, R. A., and King, E. (1968). Diagnosis of inorganic lead poisoning. A statement. British Medical Journal, 4, 501.

Lilis, R., Dumitriu, C., Roventa, A., Nestorescu, B., and Pilat, L. (1967). Renal function in chronic lead poisoning. Medicina del Lavoro, 58, 506-512.

Mahaffey, K. R., Goyer, R. A., and Wilson, M. H. (1973). Enhancement of lead toxicity by ethanol ingestion (Abstract). Federation Proceedings, 32, 262.

Malcolm, D. (1970). The effects of lead on the kidney. Transactions of the Society of Occupational Medicine, 20, 50-53.

Mao, P. and Molnar, J. J. (1967). The fine structure and histochemistry of lead-induced renal tumors in rats. American Journal of Pathology, 50, 571-581.

Mauzerall, D. and Granick, S. (1956). The occurrence and determination of $\delta$-aminolevulinic acid and porphobilinogen in urine. Journal of Biological Chemistry, 219, 435-446.

McCallum, R. I. (1963). Lead poisoning in the shipbreaking industry in Great Britain. In Epidemiology, Reports on Research and Teaching, 1962, edited by J. Pemberton. Oxford University Press, London.

Moore, M. R. I. (1972). Lead, ethanol and $\delta$-aminolaevulinate dehydratase. Biochemical Journal, 129, 43P.

Nakao, K., Wada, O., and Yano, Y. (1968). $\delta$-Aminolevulinic acid dehydratase activity in erythrocytes for the evaluation of lead poisoning. Clinica Chimica Acta, 19, 319-325.

Oliver, T. (1914). Lead Poisoning. H. K. Lewis, London.

Praetorius, E. and Poulsen, H. (1953). Enzymatic determination of uric acid with detailed directions. Scandinavian Journal of Clinical Laboratory and Investigation, 5, 273280.

Radosevic, Z., Saric, M., Beritic, T., and Knezevic, J. (1961). The kidney in lead poisoning. British Journal of Industrial Medicine, 18, 222-230.

Richet, G., Albahary, C., Ardaillou, R., Sultan, C., and MorelMaroger, A. (1964). Le rein du saturnisme chronique. Revue Française d'Études Cliniques et Biologiques, 9, 188196.

_- Morel-Maroger, L., Guillaume, P., and Galle, P. (1966). Les altérations rénales dans 23 cas de saturnisme professionnel. Bulletins et Mémoirs de la Société Médicale des Hôpitaux de Paris, 117, 441-466.

Richter, G. W., Kress, Y., and Cornwall, C. C. (1968). Another look at lead inclusion bodies. American Journal of Pathology, 53, 189-218.

Rieke, F. E. (1969). Lead intoxication in shipbuilding and shipscrapping 1941 to 1968. Archives of Environmental Health, 19, 521-539.

Selander, S. (1967). Treatment of lead poisoning. A comparison between the effects of sodium calciumedetate and penicillamine administered orally and intravenously. British Journal of Industrial Medicine, 24, 272-282.

and Cramér, K. (1968a). Determination of lead in urine by atomic absorption spectrophotometry. British Journal of Industrial Medicine, 25, 139-143.

and - (1968b). Determination of lead in blood by 
atomic absorption spectrophotometry. British Journal of Industrial Medicine, 25, 209-213.

Snyderman, S. E., Holt, L. E., Jr., Norton, P. M., Roitman, E., and Phansalkar, S. V. (1968). The plasma aminogram. I. Influence of the level of protein intake and a comparison of whole protein and amino acid diets. Pediatric Research, 2, 131-144.

Spackman, D. H., Stein, W. H., and Moore, S. (1958). Automatic recording apparatus for use in the chromatography of amino acids. Analytical Chemistry, 30, 1190-1206.

Sun, C. N., Goyer, R. A., Mellies, M., and Yin, M. W. (1966). The renal tubule in experimental lead intoxication. Archives of Pathology, 82, 156-163.

Tanquerel des Planches, L. (1839). Traités des Maladies de Plomb, ou Saturnines. Ferra, Libraire-Editeur, Paris. von Studnitz, W. and Haeger-Aronsen, B. (1962). Urinary excretion of amino acids in lead poisoned rabbits. Acta Pharmacologica et Toxicologica, 19, 36-42.

Vostal, J. and Heller, J. (1968). Renal excretory mechanisms of heavy metals. Transtubular transport of heavy metal ions in the avian kidney. Environmental Research, 2, 1-10.

Williams, M. K., King, E., and Walford, J. (1969). An investigation of lead absorption in an electric accumulator factory with the use of personal samplers. British Journal of Industrial Medicine, 26, 202-216.

Wilson, V. K., Thomson, M. L., and Dent, C. E. (1953). Amino-aciduria in lead poisoning. A case in childhood. Lancet, 2, 66-68.

Received for publication 14 May, 1973

Accepted for publication 13 August, 1973 
orthodox chemical insecticides, so each must be judged on its identified merits and test results.

For the increasing problem of schistosomiasis, mollusc control is the best tool available in practice, and effective molluscicides slowly released into water then remaining active for a few days seem the best approach. Niclosamide and Frescon seem to present insignificant risks in practice, but organotin compounds are looked upon with some doubts. Safety in drinking water supplies is the main usage requirement for new aquatic molluscicides.

Increasing resistance of rats and mice to the anticoagulant rodenticides is now a fact of life, but the committee warns against using acute rodent poisons carelessly. Red squill, norbormide, and zinc phosphide are thought to need 'ordinary care' (regrettably not defined). Acute rodenticides requiring maximal precautions (in handling, placing, disposal, and preventing access) include sodium fluoroacetate, fluoroacetamide, and strychnine. The committee regarded arsenic trioxide, white phosphorus, ANTU, and Gophacide (an organophosphate chemical) as too hazardous in use, and advise against them.

The agricultural pesticide safety programme of WHO is geared to that of FAO and ILO, and in later years joint meetings are envisaged. The committee deduced that about 500000 cases of accidental pesticide poisoning occur globally in a year, with an estimated $1 \%$ mortality. However, the real facts are scanty and ill-reported so WHO inevitably appeals for better national data in years to come. A new information function was afoot, in the provision of WHO/FAO technical and toxicological data sheets on new chemicals, as a guide for developing countries' regulatory officials and doctors. As yet, these data sheets have not emerged but have a considerable potential for good-and not just in developing countries. The committee has now become involved in the controversial 10-year-old problem of how to achieve a sound and usable system for classifying pesticides according to risk of poisoning accidents, and recommends a system which regards liquids as more hazardous than solids; supplements rat $L_{50}$ s by other cogent toxicity data; uses three risk categories (by a logarithmic progression of $\mathrm{LD}_{50} \mathrm{~s}$ ) which can also be applied to other chemicals; and ends with the much echoed hope that agreement on a tentative classification will be reached and internationally applied. Eighteen months later we are still not in that happy position, unfortunately.

On medical arrangements for pesticide intoxication emphasis is placed on official supervision and control of imports and distribution, the supply of information on toxicity and hazards of products, field methods for quick diagnosis when possible, and on analytical services for confirmatory tests.

It also emphasizes the needs for instruction in safe use, education of the rural population, specialist tuition courses for users, and the value of specialized consultants to guide new national efforts; all very good advice, and no doubt progressively being assimilated into regional plans.

It was felt that international or other transport of pesticides or treated grain must inevitably cause further occasional outbreaks of mass intoxication. The recommendation was made that WHO should be able then to assemble an emergency squad of specially knowledgeable scientists to help immediately on the spot, first for the diagnosis, control, and treatment of the emergency, then on the scientific aspects of the outbreak. Again, this is wise counsel, and the need will undoubtedly arise again somewhere, sometime soon. The current lack of doctors and scientists competently trained in pesticide toxicology was also pointed out, and increased training and tuition is urged to ease the problem.

The committee then discussed protection against chemical contamination risks in the tropics, emphasizing dermal absorption hazards, the need for an improved airpermeable but particle-resistant fabric, and pointed out the value of almost any type of clothing in protecting against dermal exposure.

Diagnosis of cholinesterase depression by blood tests presents some difficulties and potential errors with available techniques, especially from carbamate insecticides. Further research and development on methods was advocated to WHO. Organochlorine levels in blood and tissues present even greater difficulties unless undertaken in a highly sophisticated laboratory, and the committee could only urge inter-laboratory harmonization of techniques.

On therapy of pesticide poisoning, the annex adds little new to our present limited knowledge, and concentrates on organophosphate and carbamate poisoning treatment, wherein the advice is practical and sound.

This is a rather short booklet, and a rather long review: but the WHO Expert Committee does a very valuable job when it meets, and at least this reader and reviewer thus expresses his many years' gratitude to them.

E. F. EDSON

\section{Notice}

\section{Institution of Electronic and Radio Engineers}

A Conference on Environmental Sensors and Applications is being organized by the Institution of Electronic and Radio Engineers with the association of the Institution of Electrical Engineers, the Institute of Physics, and the Institute of Electrical and Electronics Engineers. It will be held at the Royal Society, London on 18 and 19 November 1974.

Further details may be obtained from the Information Officer, Institution of Electronic and Radio Engineers, 8-9 Bedford Square, London WC1B 3RG.

\section{Errata}

In the paper by Cramér, Goyer, Jagenburg, and Wilson entitled 'Renal ultrastructure, renal function, and parameters of lead toxicity in workers with different periods of lead exposure' on p. 113 of the April issue$\delta$-penicillamine should read D-penicillamine throughout. In Table 2 the heading of the third column should $\mathrm{read}$ 'Renal clearance $\left(\mathrm{ml} / \mathrm{min} / 1 \cdot 73 \mathrm{~m}^{2}\right)$. 